Research Article

\title{
Soil Erodibility Analysis and Mapping in Gilgel Gibe-I Catchment, Omo-Gibe River Basin, Ethiopia
}

\author{
Gizaw Tesfaye $\mathbb{B D}^{1}$ and Tolesa Ameyu ${ }^{2}$ \\ ${ }^{1}$ Ethiopian Institute of Agricultural Research, Melkasa Agricultural Research Centre, Adama, Ethiopia \\ ${ }^{2}$ Ethiopian Institute of Agricultural Research, Jima Agricultural Research Centre, Jima, Ethiopia \\ Correspondence should be addressed to Gizaw Tesfaye; gzwtesfaye@gmail.com
}

Received 22 September 2021; Revised 11 November 2021; Accepted 17 November 2021; Published 13 December 2021

Academic Editor: Claudio Cocozza

Copyright (C) 2021 Gizaw Tesfaye and Tolesa Ameyu. This is an open access article distributed under the Creative Commons Attribution License, which permits unrestricted use, distribution, and reproduction in any medium, provided the original work is properly cited.

\begin{abstract}
The soil erosion factor, erodibility, measures the susceptibility of soil particles to transport and detachment by erosive agents. Soil erosion and sedimentation models use soil properties and erodibility as the main input. However, in developing countries such as Ethiopia, data on soil erosion and soil-related properties are limited. For this reason, different researchers use different data sources that are adopted from a large scale and come with very different results. For this reason, the study was proposed to analyze and map the soil erodibility of the catchment area using primary data. 80 mixed soil samples were taken from the catchment with GPS coordinates and analyzed in the laboratory for soil texture class and soil organic matter. Accordingly, sandy clay loam is a dominant soil texture class covering $65 \%$ of the catchment area with $2.46 \%$ average soil organic matter, which is high in the mountainous part and lower in the lower valley of the catchment area. Most of the catchment area, which accounts for more than $78 \%$ of the area, was dominated by medium- or coarse-grained soil structure, and in the upper parts of the catchment area, $21 \%$ of the catchment area was covered with fine-grained soil structure. Similarly, $66 \%$ of the catchment area was covered with slow to moderate soil permeability, followed by slow soil permeability covering $21 \%$ of the area. Finally, the soil erodibility value of the Gilgel Gibe-I catchment was determined to be 0.046 ton $\mathrm{h} \cdot \mathrm{MJ}^{-1} \cdot \mathrm{mm}^{-1}$ with a range of 0.032 to $0.063 \mathrm{ton} \cdot \mathrm{h} \cdot \mathrm{MJ} \mathrm{J}^{-1} \cdot \mathrm{mm} \mathrm{m}^{-1}$. In general, soils with slow permeability, high silt content, and medium- to fine-grained soil structures are the most erodible. They are conveniently separate; they tend to crust and form high drainage. Knowing this, the catchment has a moderate soil erodibility value. Thus, the study recommends evidence of land cover and the protection of arable land through suitable soil and water protection measures to improve soil permeability and soil structure.
\end{abstract}

\section{Introduction}

Erodibility defines the soil's resistance to detachment and transport. Soil resistance to erosion depends on topography, land slope, and soil disturbance [1]. It is an estimate of the soil's ability to withstand erosion depending on the physical properties of each soil [2]. The erodibility of the soil varies depending on the soil texture and aggregate stability, shear strength, infiltration capacity, and soil chemical content [3]. Water erosion is accentuated by soil characteristics such as the presence of clay and destructured soils with low water permeability, which influences the hydrological properties, the water and air permeability of the soil, and the stability and arrangement of the pore space. Soil degradation is determined by natural limiting factors: unbalanced size, composition, reduced amount of humus, continental climate, and anthropogenic factors that are mainly due to classical agriculture [4]. It also measures the susceptibility of soil particles to transport and detachment based on rainfall and runoff [5]; and it is known that the best eroded soil particles are silt and very fine sand, and the less erodible soil particles are aggregated soils because they grow together, making them more resilient [6].

Many publications regard soil erodibility as a year-round constant parameter for some soils (e.g., [7]) and imply that soil erodibility can be derived from stable soil properties $[8,9]$. Other studies have shown that soil erodibility for a given soil varies depending on location, climate change, and 
human activity $[10,11]$. Hence, soil erodibility should be treated as a nonconstant term that changes in space and time; this can mislead the result of soil erosion and sedimentation rate. All soil erosion and sedimentation models use soil properties, soil erodibility, as the main entrance. Due to the limited availability of information on soil properties in developing countries, in the study area, Gilgel Gibe-I catchment, many researchers use different data sources that have been adopted on a large scale. This can lead to very different sedimentation and erosion rates in the catchment area, such as 1.1 ton $\cdot \mathrm{ha}^{-1} \cdot$ year $^{-1}$ [12], $106.68 \mathrm{ton} \cdot \mathrm{ha}^{-1} \cdot$ year $^{-1}$ [13], 0 to $127.73 \mathrm{ton} \cdot \mathrm{ha}^{-1} \cdot \mathrm{year}^{-1}$ [14], and 0.43 to $132.08 \mathrm{ton} \cdot \mathrm{ha}^{-1} \cdot$ year $^{-1}[15]$, indicating the scarcity of data sources for soil erosion as a whole country and particularly in the catchment area. For this reason, this investigation primarily aimed to analyze some soil properties through detailed soil investigations and to map the soil erodibility of the catchment area.

\section{Materials and Methods}

2.1. Description of the Study Area. The catchment area of Gilgel Gibe-I is located in the Omo-Gibe Basin in Southwest Ethiopia with a total area of $4225 \mathrm{~km}^{2}$ at the dam and is between $7^{\circ} 19^{\prime} 07.15^{\prime \prime}$ and $8^{\circ} 12^{\prime} 09.49^{\prime \prime} \mathrm{N}$ latitude and $36^{\circ} 31^{\prime} 42.60^{\prime \prime}$ and $37^{\circ} 25^{\prime} 16.05^{\prime \prime} \mathrm{E}$ longitude (Figure 1). The basin is characterized by high relief hills and mountains with an average height of around $1700 \mathrm{~m}$ above sea level. The geology of the catchment area is linked to the uplift of the East African Rift Valley in the Upper Eocene. The most important soil types in the catchment area are dominated by Nitisols, Fluvisols, Acrisols, and Vertisols. The catchment area is characterized by a humid climate with an average annual rainfall of around $1347 \mathrm{~mm}$ and an average temperature of $19^{\circ} \mathrm{C}$ to $24.78^{\circ} \mathrm{C}$. The seasonal precipitation distribution shows a unimodal pattern with a maximum in summer and a minimum in winter, influenced by the Intertropical Convergence Zone (ITCZ) [16].

2.2. Soil Survey and Analysis. From a soil depth of $0-30 \mathrm{~cm}$, depending on the topography (slope and orientation), surface coverage, and soil color variability, a total of 80 mixed soil samples were deliberately taken with a snail. The collected soil samples were subjected to a laboratory and analyzed for soil texture class and organic matter using the hydrometer method or the Walkley-Black method. The soil structure was determined during soil sampling in the field with a soil investigation manual [17], and the soil permeability rate was extracted from the soil texture classes and the permeability rate developed by Wischmeier et al. [18]. The distribution of the collected soil samples in the catchment area is shown in Figure 2.

The soil erodibility value for each soil sample location was determined using the NOMO model with the method described by Wischmeier et al. [18] being created using the following formula and a spatial soil erodibility map by interpolation according to the Kriging method in an Arc-GIS environment. In a similar way, spatial maps of the soil texture class, soil organic matter, soil structure, and soil permeability assessment of the catchment area were created by interpolation in an Arc-GIS environment with a resolution of $30 \mathrm{~m}$ cell size.

$$
K=\frac{\left[2.1 M^{1.14 *} 10^{-4}(12-a)+3.25(b-2)+2.5(C-3)\right]}{100},
$$

where $K$ is the soil erodibility, $M$ is the particle size parameter, $a$ is the percent organic matter, $b$ is the soil structure code used in soil classification, and $c$ is the soil permeability class.

This empirical equation gives soil erodibility value in US units [18], and according to Foster et al. [19], the value in US units must be multiplied by 0.1317 to be converted into SI units.

\section{Results and Discussion}

3.1. Soil Textural Class. Soil texture (which refers to the relative proportion of sand, silt, and clay) is an essential characteristic that contributes to the erodibility of the soil. Compared to soils with more clay particles, soils with more sand particles are prone to erosion. Sandy clay loam covers more than $65 \%$ of the catchment area, followed by sandy loam (32\%), and sandy loam covers less than $3 \%$ of the total catchment area (Figure 3).

Erodibility of the soil is low for clay-rich soils with a low shrinkage swelling capacity since clay particles agglomerate and form large aggregates that withstand the detachment and transport process. In essence, sand, sandy loam, and loamy soils are less erodible than silt, very fine sand, and certain clayey soils [20].

3.2. Soil Organic Matter. Soil organic matter (SOM) is a binder that binds mineral particles together to form a soil structure, and soils with high SOM are more resistant to erosion. Soil organic matter influences the soil erodibility, infiltration, water retention, and shear reliability of the soil, which influences soil erodibility [21]. The highest value was $5.15 \%$ (near the mouth of the river basin). Then, the mean SOM of the catchment area was found to be 3.82 with a standard deviation of 0.49 . Soils with less than $2 \%$ organic matter can be considered erodible [22]. Soils with a higher proportion of organic matter and improved structure are more resistant to erosion $[23,24]$. The soils of the catchment area are resistant to erosion as the minimal SOM of the catchment area was $2.487 \%$, which is more than $2 \%$. The spatial distribution of the SOM of the catchment area is shown in Figure 4 and is high on the hill segments covered with forest and coffee-based agroforestry and less in the lower valley of the catchment area.

3.3. Soil Structure and Permeability. Soil structure is understood to mean the orientation of soil particles in the soil. Soils with poor soil structure near the soil surface are dangerous for runoff formation. Permeability describes the 


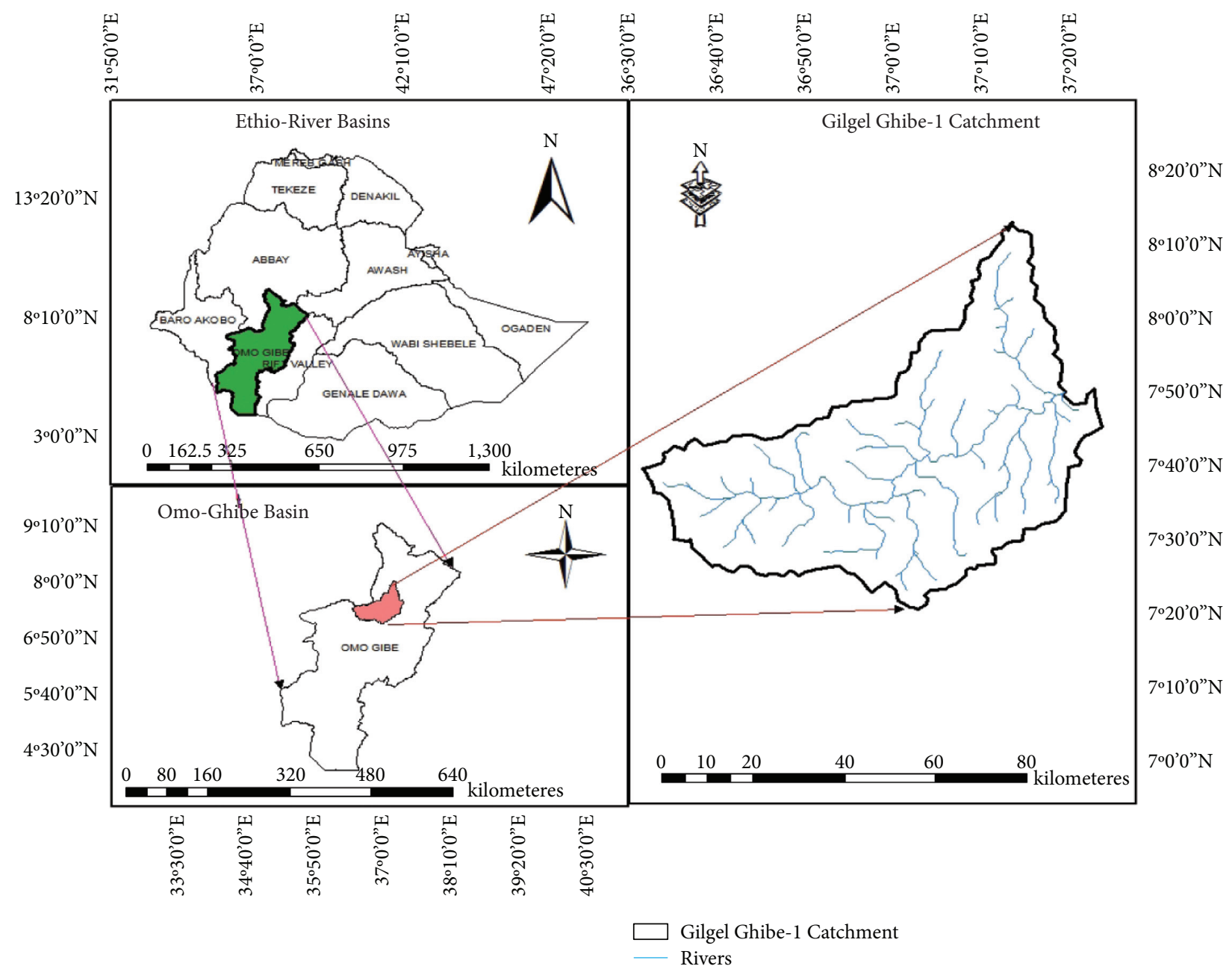

FIgURE 1: Location map of the study area.

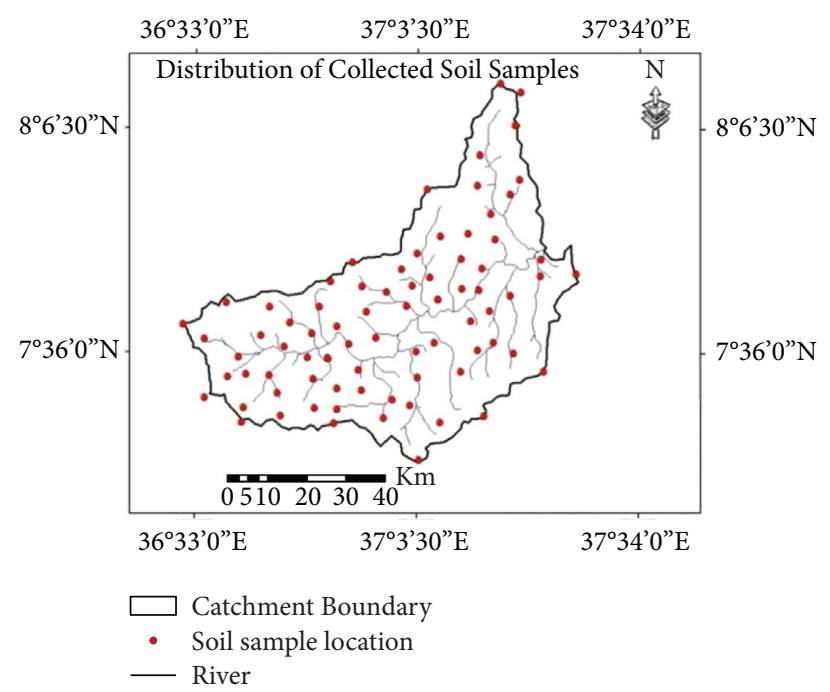

FIGURE 2: Soil sample location map for soil characteristics' analysis. 

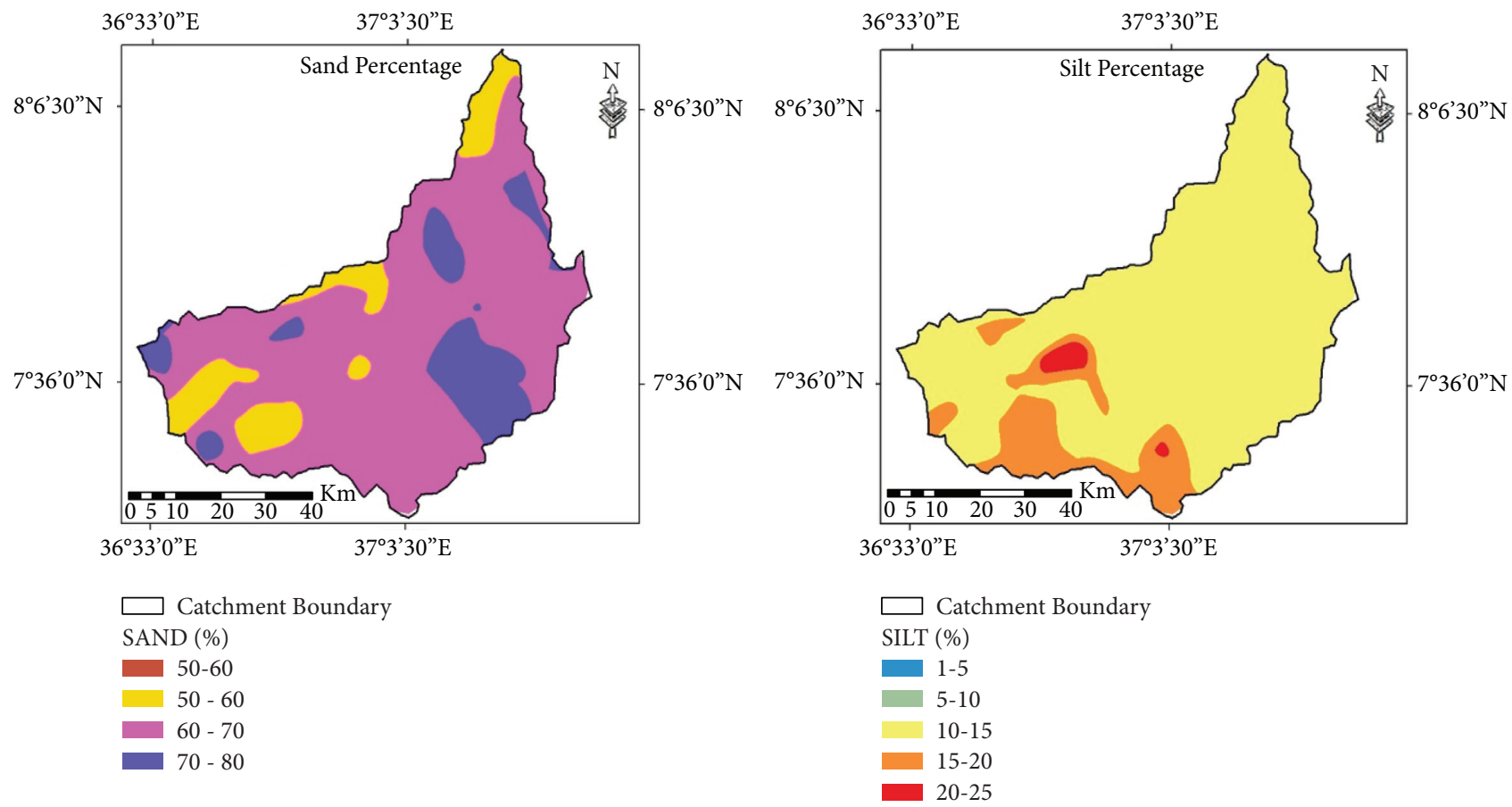

(a)
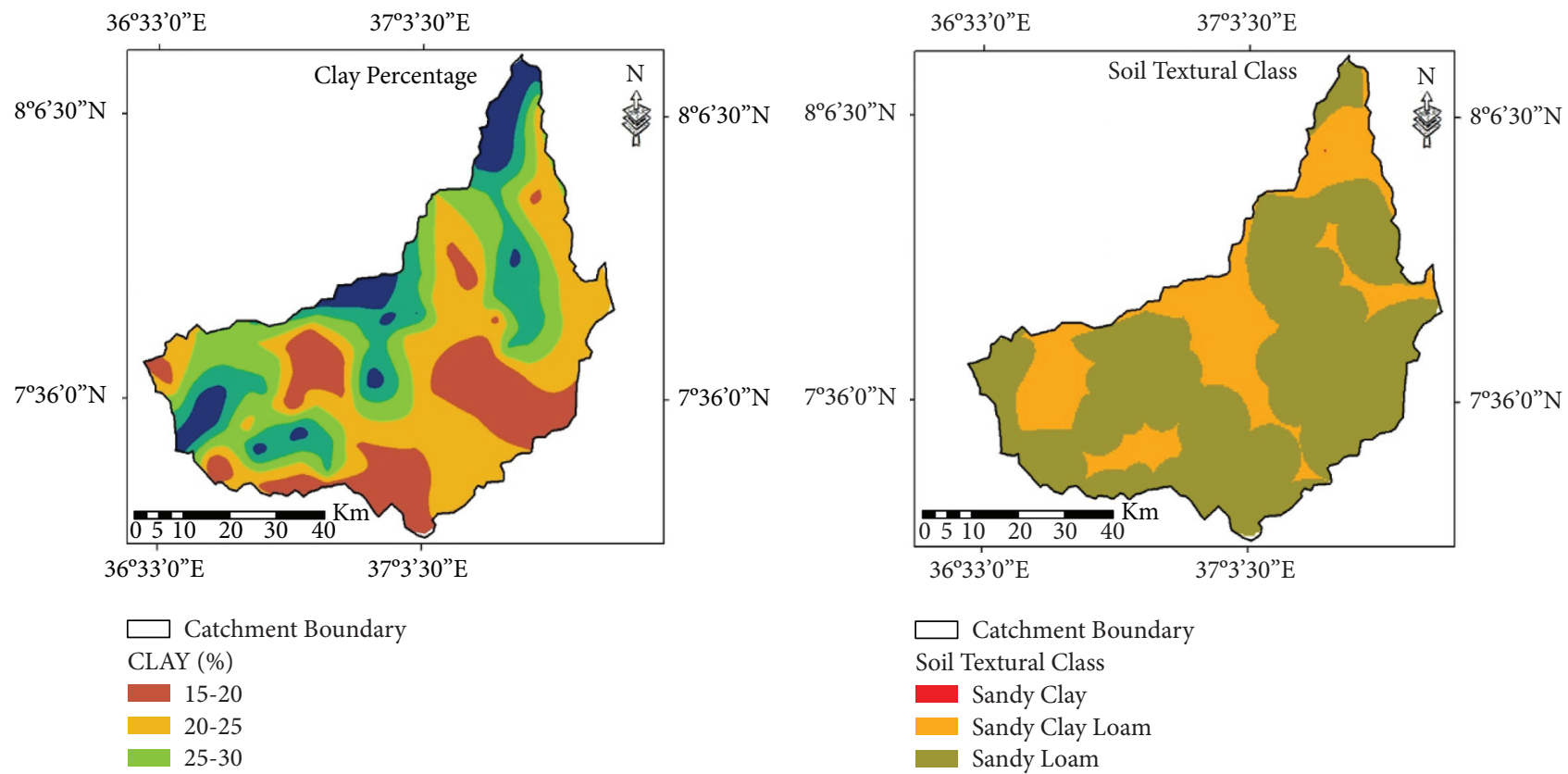

$\square$ Catchment Boundary

CLAY (\%)

$15-20$

20-25

25-30

30-35

35-40

(d)

Figure 3: Spatial map of sand percentage (a), silt percentage (b), clay percentage (c), and soil textural class (d). 


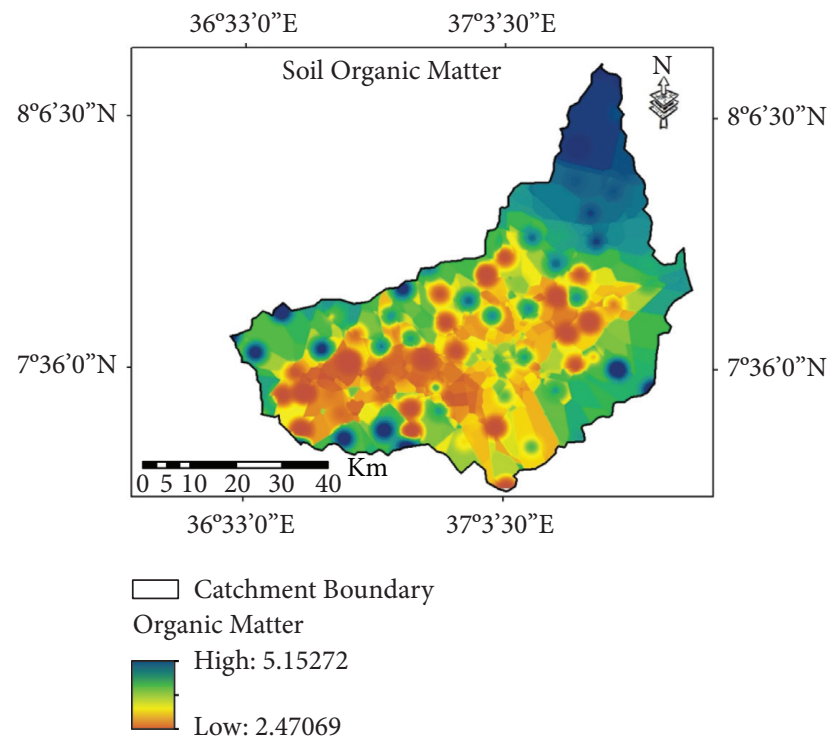

FIgURe 4: Spatial map of soil organic matter.

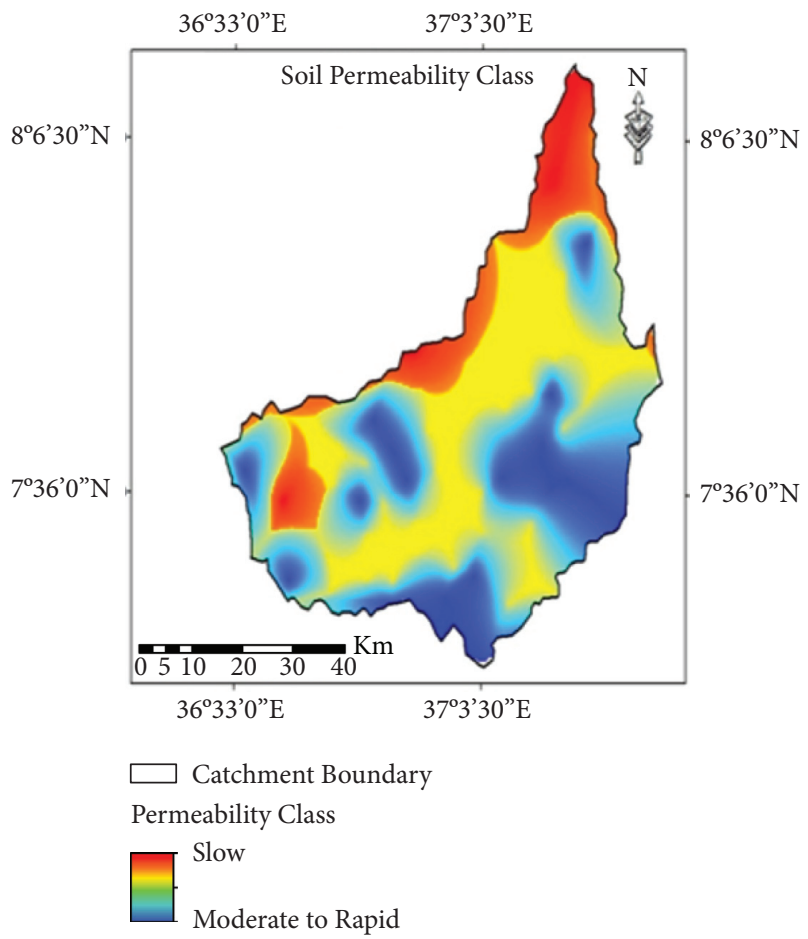

(a)

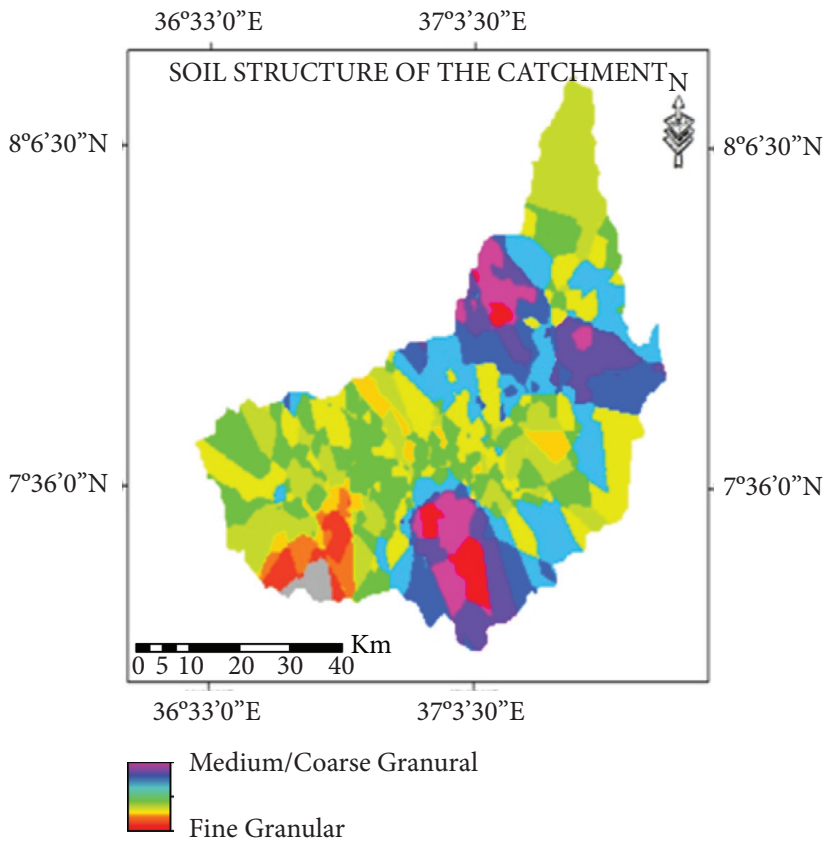

(b)

FIGURE 5: Spatial map of the soil permeability class (a) and soil structure (b).

ability of the soil to transfer water, which depends on the pores in the soil and their connection. The slow to moderate soil permeability comprised $66 \%$ of the catchment area, and $21 \%$ of the catchment area was covered by slow soil permeability. And only $12.7 \%$ of the catchment area has moderate soil permeability (Figure 5(a)). In most parts of the catchment area (at high altitudes and in the lower valleys), a medium- or coarse-grained soil structure dominates, which makes up more than $78 \%$. The fine-grained soil structure also covers approximately $21 \%$ of the catchment area, mainly the upper section of the catchment area (Figure 5(b)).

3.4. Soil Erodibility Value Map of the Catchment. Soil erodibility embodies an intrinsic resistance to particle detachment (degradation) and transport through precipitation. It is determined by the cohesive force between the soil particles, which can change depending on the existing or low 


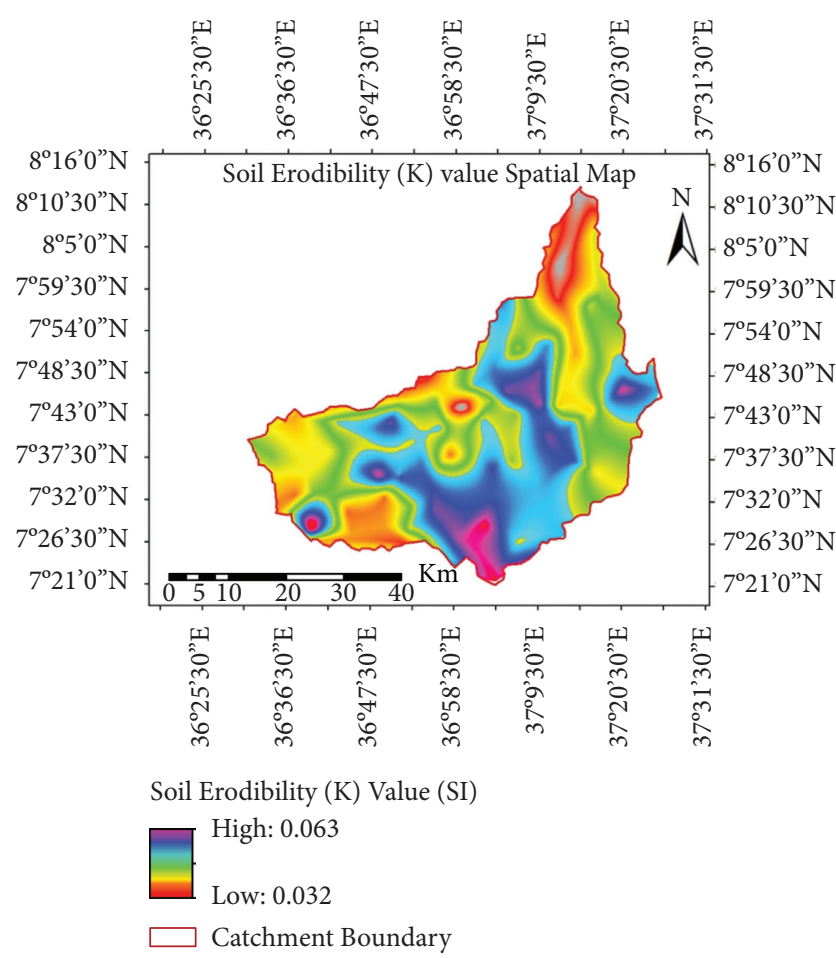

FIGURE 6: Spatial soil erodibility map of Gilgel Gibe-I catchment.

plant cover, the water content of the soil, and the growth of its structure. The mean weighted soil erodibility value of the Gilgel Gibe-I area was 0.35 ranging from 0.28 to 0.41 in US units and 0.046 ton.h. $\mathrm{MJ}^{-1} \cdot \mathrm{mm}^{-1}$ with a range of 0.032 to 0.063 ton $\cdot h \cdot \mathrm{MJ}^{-1} \cdot \mathrm{mm}^{-1}$ in SI units which is commonly used (Figure 6).

Soils with a high silt content are the most erodible of all soils, and usually, soil erodibility values for such soils are above 0.4, but Gilgel Gibe-I catchment soil texture is dominated with sandy clay loam, which accounts for $65 \%$ of the area. According to Goldman et al. [25], the soil erodibility value for all soils is in the range of 0.02 to 0.69 if all determinants remain constant. In line with [25], the mean annual soil erodibility of the Gilgel Gibe-I catchment is found in the range which is $0.046 \mathrm{ton} \cdot \mathrm{h} \cdot \mathrm{MJ}^{-1} \cdot \mathrm{mm}^{-1}$.

\section{Conclusion and Recommendation}

Soil erodibility is so complicated because of several factors that affect the spatial and temporal variability of soil loss. Soil texture, organic matter content, soil structure, and permeability were important soil properties that could influence soil erodibility. The map and the spatial soil erosion value make a valuable contribution to the estimation of soil erosion in the catchment area of Gilgel Gibe-I since the $K$-factor is an essential input that is used in many soil erosion and hydrological models. The influence of these factors on reducing the erodibility of the soil is due to its role in the formation of aggregates and their stability.

The Gilgel Gibe-I catchment showed that sandy clay loam (65\%) dominated the catchment, followed by sandy loam (32\%), making the soils in the catchment moderately erodible. The soil organic matter in the catchment area was more than $2 \%$. The permeability rate was observed to be slow to moderate and covers $66 \%$ of the catchment area. $78 \%$ of the catchment area was covered with a medium- or coarse-grained soil structure. In the catchment area of Gilgel Gibe-I, soil erodibility values between 0.032 and 0.063 were found with a mean value of 0.046 ton $\cdot \mathrm{h} \cdot \mathrm{MJ}^{-1} \cdot \mathrm{mm}^{-1}$ for the occurrence of surface runoff in which fine soil particles are removed with moderate soil erodibility of the catchment area. For this reason, land management practice (biophysical, soil, and water protection measures with agronomic practices) is strongly recommended to reduce surface runoff and improve soil infiltration rate. In addition, scientists need to validate large-scale secondary soil data with primary soil data before using them for further analysis and conclusions.

\section{Data Availability}

All the data used to support the findings of this study are included within the article.

\section{Conflicts of Interest}

The authors declare that they have no conflicts of interest.

\section{References}

[1] D. Niu, H. Wang, and L. Lai, "Soil erosion and conservation," 2003, http://159.226.205.16/curriculum/3w/01/cause/index. html.

[2] J. J. Musa, S. C. Anijofor, P. Obasa, and J. J. Avwevuruvwe, "Effects of soil physical properties on erodibility and infiltration parameters of selected areas in Gidan Kwano," Nigerian Journal of Technological Research, vol. 12, no. 1, p. 46, 2017.

[3] R. Evans, "Mechanics of water erosion and their spatial and temporal control: an empirical viewpoint," in Soil Erosion, M. J. Kirkby and R. P. C. Morgan, Eds., pp. 109-128, Wiley, Chichester, UK, 1980.

[4] L. Tamara, "Soil degradation and conservative technologies: two incompatible realities for Republic of Moldova," Journal of BioFlux ProEnvironment, vol. 6, pp. 136-143, 2013.

[5] K. G. Renard, G. Foster, G. Weesies, D. McDool, and D. Yoder, "Predicting soil erosion by water: a guide to conservation planning with the revised universal soil loss equation (RUSLE)," in Agricultural Handbook 703USDAARS, Beltsville, MD, USA, 1997.

[6] H. S. Kim, "Soil erosion modeling using RUSLE and GIS on the IMHA watershed," Water Engineering Research, vol. 7, no. 1, 2006.

[7] Hudson, Soil Conservation, Iowa State University Press, Ames, IA, USA, Third edition, 1995.

[8] R. Lal, "Soil structure and sustainability," Journal of Sustainable Agriculture, vol. 1, no. 4, pp. 67-92, 1991.

[9] B. Y. Liu, K. L. Zhang, and J. Y. Jiao, "Soil erodibility and its use in soil erosion prediction model," Journal of Natural Resources, vol. 14, pp. 345-350, 1999.

[10] D. Torri, J. Poesen, L. Borselli, and A. Knapen, "Channel width-flow discharge relationships for rills and gullies," Geomorphology, vol. 76, no. 3-4, pp. 273-279, 2006. 
[11] M. P. Salvador Sanchis, D. Torri, L. Borselli, and J. Poesen, "Climate effects on soil erodibility," Earth Surface Processes and Landforms, vol. 33, pp. 1082-1097, 2007.

[12] F. Tufa, "Sediment management in reservoir, case study of Gilgel Gibe-I dam," Addis Ababa University, Addis Ababa, Ethiopia, Degree of Masters of Science in Civil Engineering Under Hydraulics Engineering, 2016.

[13] R. Devi, E. Tesfahune, W. Legesse, B. Deboch, and A. Beyene, "Assessment of siltation and nutrient enrichment of Gilgel Gibe dam, Southwest Ethiopia," Bioresource Technology, vol. 99, no. 5, pp. 975-979, 2008.

[14] T. Adugna, F. Saathoff, Y. Seleshi, and A. Gebissa, "Evaluating the effectiveness of best management practices in Gilgel gibe basin watershed-Ethiopia," Journal of Civil Engineering and Architecture, vol. 7, no. 10, pp. 1240-1252, 2013.

[15] T. Negash and K. Mesfin, Proceeding of the National Workshop on Integrated Watershed Management in Gibe-Omo Basin, PHE Ethiopia Consortium, Addis Ababa, Ethiopia, 2013.

[16] S. F. Demissie, Y. Sileshi, and A. Gebissa, "Climate change impacts on the stream flow and simulated sediment flux of Gilgel Gibe 1 hydropower reservoir in Ethiopia," European International Journal of Science and Technology, vol. 2, no. 2, 2013.

[17] SSM, C. Ditzler, K. Scheffe, and H. C. Monger, Soil Survey Manual: Soil Science Division Staff, USDA Handbook 18. Government Printing Office, Washington, DC, USA, 2017.

[18] W. H. Wischmeier, C. B. Johnson, and B. V. Cross, "A soil erodibility nomograph for farmland and construction sites," Soil Water Conser, vol. 26, pp. 189-193, 1971.

[19] G. R. Foster, D. K. McCool, K. G. Renard, and W. C. Moldenhauer, "Conversion of the universal soil loss equation to SI metric units," Journal of Soil and Water Conservation, vol. 36, no. 6, pp. 355-359, 1981.

[20] A. T. ÓGeen, R. Elkins, and D. Lewis, Division of Agriculture and Natural Resources, University of California, Santa Barbara, CA, USA, 2006.

[21] A. Belasri, A. Lakhouili, and O. Iben Halima, "Soil erodibility mapping and its correlation with soil properties of Oued El Makhazine watershed, Morocco," Journal of Materials and Environmental Sciences, vol. 8, no. 9, pp. 3208-3215, 2017.

[22] J. Boardman, "Soil erosion science: reflection on the limitations of approach," Catena, vol. 68, no. 2/3, pp. 73-86, 2006.

[23] J. Leonard, O. Ancelin, B. Ludwig, and G. Richard, "Analysis of the dynamics of soil infiltrability of agricultural soils from continuous rainfall-runoff measurements on small plots," Journal of Hydrology, vol. 326, no. 1-4, pp. 122-134, 2006.

[24] V. A. D. Oliveira, C. R. D. Mello, M. F. Durães, and A. M. D. Silva, "Soil erosion vulnerability in the Verde River Basin, Southern minas gerais," Ciencia E Agrotecnologia, vol. 38, no. 3, pp. 262-269, 2014.

[25] S. J. Goldman, K. Jackson, and T. A. Bursztynsky, Erosion and Sediment Control Handbook, McGraw Hill Book Co., New York, NY, USA, 1986. 